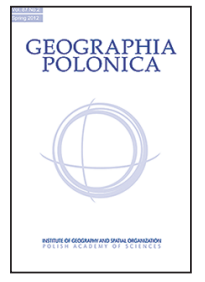

\title{
INFLUENCE OF THE CZORSZTYN-SROMOWCE WYŻNE RESERVOIR COMPLEX ON THE DUNAJEC RIVER THERMAL-REGIME
}

\section{Łukasz Wiejaczka1 • Małgorzata Kijowska-Strugała ${ }^{2}$ - PawełPierwoła ${ }^{3}$ • Mariusz Nowak ${ }^{3}$}

\author{
${ }^{1}$ Institute of Geography and Spatial Organization \\ Polish Academy of Sciences \\ św. Jana 22, 31-018 Krakow: Poland \\ e-mail: wieja@zg.pan.krakow.pl \\ ${ }^{2}$ Institute of Geography and Spatial Organization \\ Polish Academy of Sciences \\ 38-311 Szymbark 430 Szymbark: Poland \\ e-mail: mkijowska@zg.pan.krakow.pl \\ ${ }^{3}$ The Hydroelectric Power Plants Complex ZEW Niedzica S.A. \\ Widokowa 1, 34-441 Niedzica: Poland \\ e-mails: pawel.pierwola@niedzica.pl・mariusz.nowak@niedzica.pl
}

\begin{abstract}
The main objective of this paper was to demonstrate the changes in the natural thermal regime of the middle course of the Dunajec River, caused by the construction of the reservoir complex in the villages of Czorsztyn and Sromowce Wyżne 1994-1997. The analysis is based on water temperature measurements conducted in the river longitudinal profile, four times at the turn of 2012/2013 under hydrometeorological conditions for each season of the year. The field research results were expanded to include an analysis of archival materials relating to the temperature of the Dunajec River, in the hydrological years from 1984 to 2007, at the village of Krościenko's water-gauging station. The station is located approximately $22 \mathrm{~km}$ downstream from the Czorsztyn and Sromowce Wyżne Reservoirs. The analysis showed that the formation of the CzorsztynSromowce Wyżne Reservoir Complex caused a distinct change in the thermal regime of the mid-Dunajec River. Under favorable conditions these changes reach the Rożnów-Czchów Reservoir Complex.
\end{abstract}

\section{Key words}

Carpathians • Czorsztyn Reservoir • Dunajec River • Sromowce Wyżne Reservoir • water temperature 


\section{Introduction}

Storage reservoirs lead to significant changes in the natural thermal regime of rivers. Upstream from reservoirs, the temperature of the river water is shaped by weather conditions (mainly air temperature) and the temperature of groundwater and surface tributaries. Downstream from reservoirs the temperature of the river water depends on the thermal conditions emerging within the water. It is only at a distance from the dam, that the influence of natural factors increases. Creating reservoirs interrupts the thermal continuum of rivers, but a reservoir's impact may vary depending on: the parameters of the reservoir, the reservoir's functions, and the natural characteristics of rivers.

The main research issues deal with how the direction (warming, cooling), the scale, and scope of impact of reservoirs affect the temperature of rivers. While the effect of one reservoir on a river thermal regime is relatively easy to predict, any interaction involving several reservoirs is a more complex process.

In the world literature, the issue of river temperature changes which take place downstream from reservoirs, is generally discussed in the hydrobiological context (e.g. Webb \& Walling 1993; Lessard \& Hayes 2003; Frutiger 2004), as water temperature is an important regulator of biological life in rivers (Allan \& Castillo 2007). Such research in the Polish Carpathians mainly concerned the Dunajec River and the Rożnów-Czchów Reservoir Complex (among others: Chomiak 1962; Tomik 1969; Cyberska 1972, 1975; Punzet 1991), and the Ropa River and the Klimkówka Reservoir (among others: Wiejaczka 2007a,b, 2011; Smołkowicz et al. 2014; Soja \& Wiejaczka 2014).

Particularly relevant are the publications by Cyberska (1972, 1975). Based on archival materials and field tests, the author of the publications characterises in detail the scale and scope of the impact the Rożnów-Czchów Reservoir Complex created in the years 1941-1949. The publications cover the impact the Rożnów-Czchów Reservoir Complex had on water temperature in the lower reach of the Dunajec River, and the dynamics of the thermal conditions in these reservoirs. The author showed that the interaction involves the waters of the Dunajec River as far as to the confluence with the Vistula. The author drew our attention to the relationship between water temperature flowing out from the reservoirs and the thermal processes taking place there, and the intensity of the exchange of water in the reservoirs. The higher the frequency, the smaller the increase in the temperature of the water in rivers. The author also noted that there was a shortening of the period of ice on the Dunajec River, and a reduced thickness of ice cover.

Changes in the thermal regime of the lower reach of the Dunajec River caused by the construction of the Rożnów-Czchów Reservoir Complex, were examined in the literature cited above. However, there has not been a study of the water temperature changes of the middle reach of the river downstream from the Czorsztyn-Sromowce Wyżne Reservoir Complex that was put into operation in the years 1994-1997. The main objective of this paper was to demonstrate the seasonal changes in the natural thermal regime of the Dunajec River middle reach, as caused by the functioning of the Czorsztyn-Sromowce Wyżne Reservoir Complex. In the analysis, attention was paid to the differences between the impact of complex reservoirs and the single dam reservoir, on the thermal regime of the river.

\section{Subject of the study}

The Dunajec River is a right-bank Carpathian tributary of the Vistula River. It arises from a connection of the White and Black Dunajec River, in the city of Nowy Targ (Fig. 1), and flows through the Podhale area, the Pieniny Mountains, the Western Beskids, the Carpathian Foothills, and the Sandomierz Basin. The river's course can be divided into three sections. The first section is from the springs to the Czorsztyn-Sromowce Wyżne Reservoir 


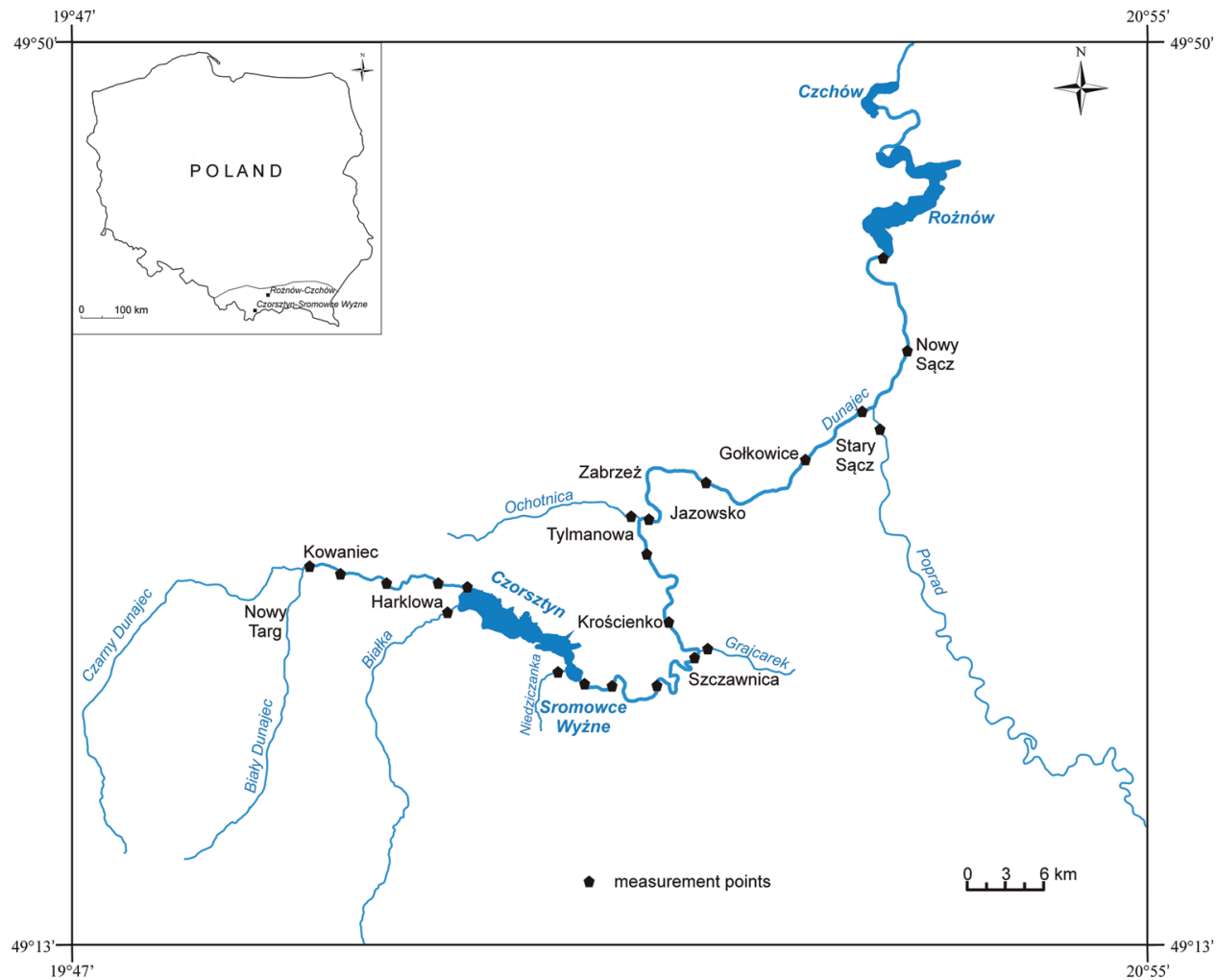

Figure 1. The study area

Complex where it drains water from the Tatras and the Podhale region and is characterised by a high proportion of underground contributions (Dynowska 1971). The second section of the Dunajec River is limited to the cascades of the Czorsztyn-Sromowce Wyżne and the Rożnów-Czchów Reservoirs. The course flows are strongly influenced by: (a) water management conducted on the first two reservoirs, (b) the Poprad River the Dunajec tributary in the vicinity of town of Stary Sacz, (c) smaller streams flowing from the Gorce areas, the Pieniny, and the Beskid Wyspowy mountain range. The hydrological regime of the Dunajec River in the third section, downstream from the Rożnów-Czchów Reservoirs, is under the influence of these reservoirs.

The Sromowce Wyżne Reservoir started functioning in 1994 and acts as a balancing reservoir for the Czorsztyn Reservoir.
The dam of the Sromowce Wyżne Reservoir, with a height of $13 \mathrm{~m}$ and a length of $460 \mathrm{~m}$, is located at the $171.4 \mathrm{~km}$ point of the river's course. The length of the reservoir is approx. $2 \mathrm{~km}$, the width - $0.75 \mathrm{~km}$, the maximum depth - approx. $10 \mathrm{~m}$, the surface - $88 \mathrm{ha}$, and the total capacity $-7.42 \mathrm{mln} \mathrm{m}^{3}$. At the dam, there is a river-run power plant with a total capacity of $2.08 \mathrm{MW}$, capable of annual electricity production at the level of $9.1 \mathrm{GWh}$. Due to the large fluctuations in water level (up to $6.5 \mathrm{~m}$ per day), the area is not used for recreational purposes (Kloss 2003).

The Czorsztyn Reservoir project was launched in 1997. The dam of the Czorsztyn Reservoir is $56 \mathrm{~m}$ high and $404 \mathrm{~m}$ long and is located at the $173.3 \mathrm{~km}$ point of the river. The reservoir capacity is $231.9 \mathrm{mln}$ $\mathrm{m}^{3}$, and the surface, at the maximum flood impoundments is 1226 ha. The reservoir 
is $10 \mathrm{~km}$ long, the width is $0.4-2.0 \mathrm{~km}$, and the depth in the vicinity of the dam is up to 50 meters (the average at the maximum impoundment is approx. $17.6 \mathrm{~m})$. This artificial body of water functions mainly as flood protection of the Dunajec River Valley and increasing the Dunajec River Valley's minimum flows. The Czorsztyn Reservoir's power plant, with a capacity of $92 \mathrm{MW}$ per year, produces about 79.5 GWh of electricity (Kloss 2003).

The guaranteed outflow of the CzorsztynSromowce Wyżne Reservoirs is $12 \mathrm{~m}^{3} \cdot \mathrm{s}^{-1}$ in the period from 1 April to 31 October, and $9 \mathrm{~m}^{3} \cdot \mathrm{s}^{-1}$ in the period from 1 November to 31 March.

\section{Research methodology}

Analysis of the temporal and spatial dynamics of water temperature in the CzorsztynSromowce Wyżne Reservoirs was based on measurements taken during the summer (4 July 2012), autumn (9 November 2012), winter (15 February 2013), and spring (29 April 2013 ) in selected hydrometric vertical profiles (Wiejaczka et al. 2014). The vertical profiles were arranged in three cross-sections of the Czorsztyn Reservoir (in the lower, middle, and backwater parts), and in one cross-section of the Sromowce Wyżne Reservoir. In the dam and middle part of the Czorsztyn Reservoir, 6 hydrometric vertical profiles were selected for the measurements, and they were located every $200 \mathrm{~m}$. In the upper part, 8 vertical profiles were located. On the Sromowce Wyżne Reservoir, 8 vertical profiles were assigned (every $100 \mathrm{~m}$ ). The measurements were performed using an electronic thermometer with a probe connected to the meter with a wire.

To capture the scale and range of the reservoir's influence on water temperature in the longitudinal profile of the Dunajec River, from the city of Nowy Targ (downstream the White and Black Dunajec River) to the mouth of the Rożnów Reservoir, water temperature measurements were carried out at selected points near the bank (Fig. 1). The measurements were conducted four times, at the end of 2012/ beginning of 2013 (on the same days as the thermal measurements of the water in the reservoirs were conducted) under hydrometeorological conditions typical for each season (in the afternoon, at the maximum, daily air temperature values). The measurements carried out downstream and upstream from the Czorsztyn-Sromowce Wyżne Reservoir Complex allowed for illustrating the longitudinal thermal profile of the upper and middle reaches of the Dunajec River.

The results of the field research were expanded to include an analysis of archival materials provided by the Institute of Meteorology and Water Management for the Krościenko water-gauging station located at the $149.9 \mathrm{~km}$ point of the river course, at a distance of approx. $22 \mathrm{~km}$ from the reservoir complex (Fig. 1). The study uses data on water temperature (measured at 6:00 UTC) of the following hydrological years: 1984-1993 and 1998-2007. These two decades represent the annual cycle of the Dunajec River water temperature before and after the construction of the Czorsztyn-Sromowce Wyżne Reservoir Complex. The average value of water temperature for each month from the period 1984-1993 and 1998-2007 were analysed statistically using non-parametric Mann-Whitney $U$ test.

\section{Temporal and spatial dynamics of the water temperature in the Czorsztyn-Sromowce Wyżne Reservoir Complex}

Detailed results of the thermal conditions in the Czorsztyn-Sromowce Wyżne Reservoir Complex are presented in the paper by Wiejaczka et al. (2014). When considering the water temperature changes in the river downstream from its dams, it is the thermal conditions forming in the dam part of the reservoirs that are essentially responsible for the temperature of the out-flowing water. The study of water temperature in the Czorsztyn Reservoir showed typical dynamics of thermal conditions for the Carpathian retention reservoirs during the year (Fig. 2). Vertical temperature 


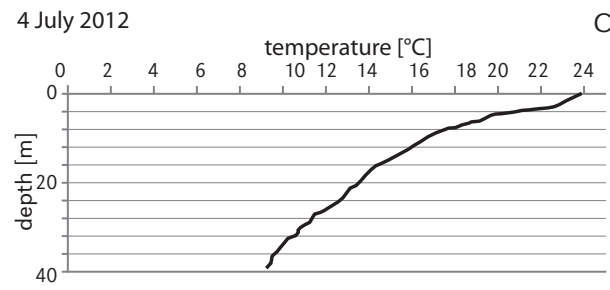

Czorsztyn

15 February 2013
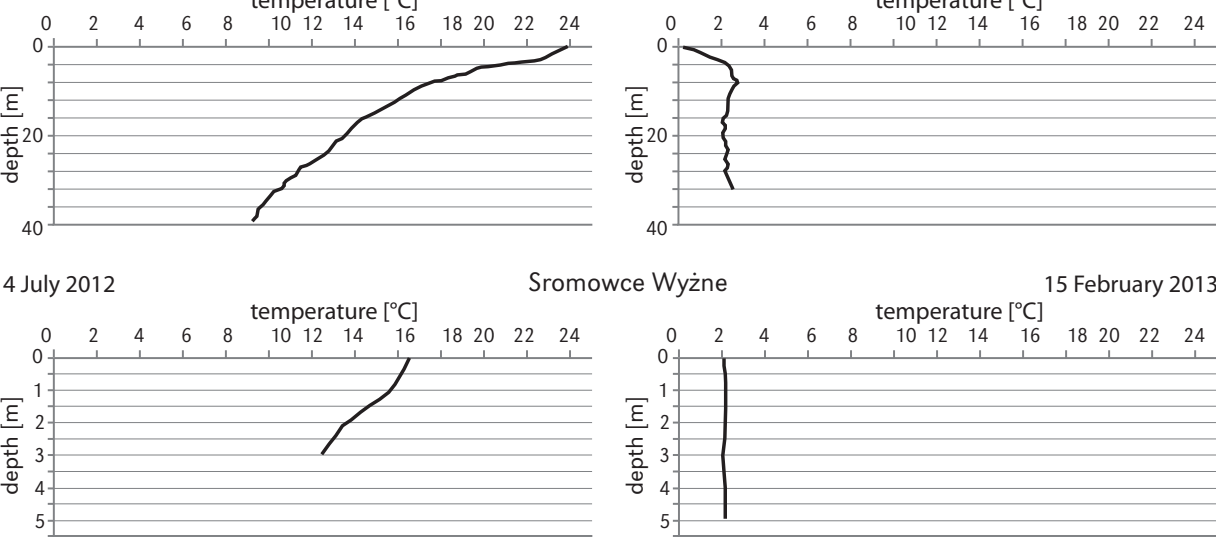

Sromowce Wyżne

15 February 2013

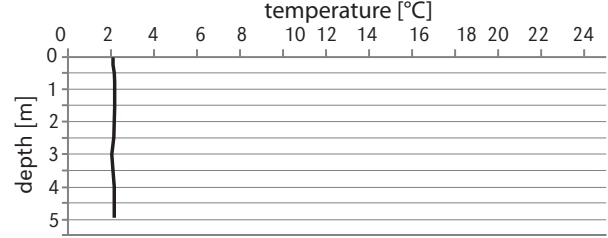

Figure 2. Average water temperature in the vertical profile of the Czorsztyn (dam part) and the Sromowce Wyżne Reservoirs (according to Wiejaczka et al. 2014)

stratification developed during the summer measurements with a vertical, temperaturedrop of several degrees between the surface $\left(23.9^{\circ} \mathrm{C}\right)$ and the reservoir $\left(9.4^{\circ} \mathrm{C}\right)$. The average temperature throughout the vertical hydrometric vertical profiles the dam portion, was $14.6^{\circ} \mathrm{C}$. Thermocline was observed to be between 3 and $5 \mathrm{~m}$. The water temperature of the whole Czorsztyn Reservoir was a little uneven during the autumn measurements. Water temperature in the reservoir at the dam part was $9.0-9.5^{\circ} \mathrm{C}$. During the winter measurements, the average water temperature under the ice was $0.1^{\circ} \mathrm{C}$. Typical winter season temperature-stratification was seen in the vertical profile. Rapid temperature rise occurred to a depth of $4 \mathrm{~m}$ (from $0.1^{\circ} \mathrm{C}$ to $2.3^{\circ} \mathrm{C}$ ). The maximum value $\left(2.6^{\circ} \mathrm{C}\right)$ was recorded at the bottom, at a depth of $32 \mathrm{~m}$ (the average was $2.2^{\circ} \mathrm{C}$ ). In the spring measurements, at the dam part of the reservoir, two vertical zones were distinguished with different thermal conditions, but no broader transition layer was observed. Water temperature ranged from $14.8^{\circ} \mathrm{C}$ to $3.6^{\circ} \mathrm{C}$. Such a temperature range meant that in the deeper parts of the reservoir, the values were characteristic of winter (below $4^{\circ} \mathrm{C}$ ).

At the Sromowce Wyżne Reservoir, in the summer period, the average temperature of the water's surface layer showed a significantly lower value, as compared with that of the Czorsztyn Reservoir (Fig. 2), from which cooler water flowed. The water was not deep and there was a rapid exchange of water in the reservoir, which meant that stratification in the Sromowce Wyżne Reservoir was difficult. In the summer, the Sromowce Wyżne Reservoir) reduces the main reservoir's cooling impact on the water temperature of the Dunajec River. In the autumn, the temperature of the water in the Sromowce Wyżne Reservoir showed relative homeothermy $\left(8.9-8.2^{\circ} \mathrm{C}\right)$, as in the Czorsztyn Reservoir. Under the hydrometeorological conditions occurring during the autumn measurements, the Sromowce Wyżne Reservoir reduced the main reservoir's warming impact on the water of the Dunajec River. In the winter, ice cover was observed only in the central part of the water reservoir. In the vertical profile at the dam (5 $\mathrm{m}$ in depth, no ice cover on the surface), there was no change in temperature $\left(2.2-2.1^{\circ} \mathrm{C}\right)$. In the part devoid of ice cover, there was no stratification similar to that which occurred in the Czorsztyn Reservoir. There was also no apparent influence on the temperature of the water flowing from the main reservoir. During the spring measurements in the Sromowce Wyżne Reservoir, 
as well as in the summer and autumn, there was a decrease in the water temperature and the depth. The temperature of the water in the reservoir was within $5.5-4.5^{\circ} \mathrm{C}$. The Sromowce Wyżne Reservoir decreased the cooling influence of the Czorsztyn Reservoir which then affected the water temperature of the Dunajec River.

The analysis of thermal conditions in the Czorsztyn-Sromowce Wyżne Reservoir Complex indicates that the presence of a balancing reservoir may diminish the direction (cooling, warming) and the scale in the thermal regime of the river changes caused by the operation of the main reservoir. When considering the natural thermal regime of rivers, construction of a retention reservoir complex is, therefore, more beneficial than constructing individual objects.

\section{Changes in the longitudinal thermal profile of the Dunajec River as a result of the impact of the Czorsztyn-Sromowce Wyżne Reservoir Complex}

\section{Temperatures of the Dunajec River before the construction of the reservoirs}

The general characteristics of the Dunajec River thermals, not changed by the operation of the Czorsztyn-Sromowce Wyżne Reservoir Complex, was presented by Gołek (1961). The study shows that the average Dunajec River water temperature at the Waksmund-Czorsztyn section, in individual months of the year, slightly increased (Fig. 3). According to the author, this increase was favored by numerous backwaters and shallows, posing the possibility of a more rapid heating of the water. From Czorsztyn to Jazowsko, the water temperature of the Dunajec River significantly increased during the summer. In the winter, no major changes took place. This proves the sole influence of air temperature on the temperature of the Dunajec River water. Water heated from air masses was, at this section, favored by the compact river channel which had a rock-rubble bed. There were no major impacts on the water temperature of the Dunajec River from the numerous tributaries. From downstream Jazowsko, to the Rożnów Reservoir backwater, there were no major changes in river thermals. River thermals of this section was also not affected by the Poprad River (the right-bank tributary of the Dunajec River), which indicates that the water temperature of Poprad River was close to that of the Dunajec River.

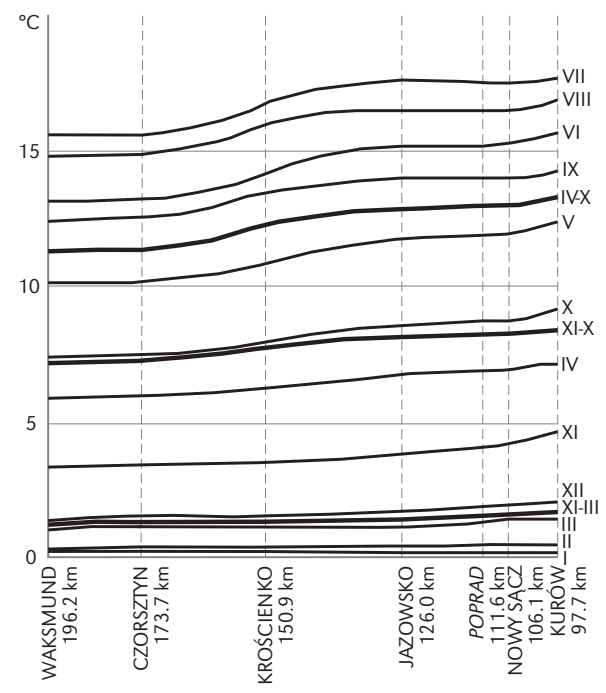

Figure 3. Average water temperatures in the longitudinal profile of the Dunajec River between Waksmund and Kurów in the 1947-1956 period (according to Gołek 1961)

An example of a longitudinal thermal profile of the upper and middle reaches of the Dunajec River (between the town of Nowy Targ - $198.6 \mathrm{~km}$ of the river-course, and the village of Tegoborze - $105 \mathrm{~km}$ ) in the summer (6 August) and in the winter (15 February) in 1993, just before the construction of the reservoirs, is shown in Figure 4. Every year, at the time of maximum air temperature, the middle course of the Dunajec River underwent an increase in water temperature from $19.4^{\circ} \mathrm{C}$ to $23.9^{\circ} \mathrm{C}$. In the winter season (with negative values of daily air temperature), from the location of the town of Nowy Targ to the town of Krościenko, water tem- 


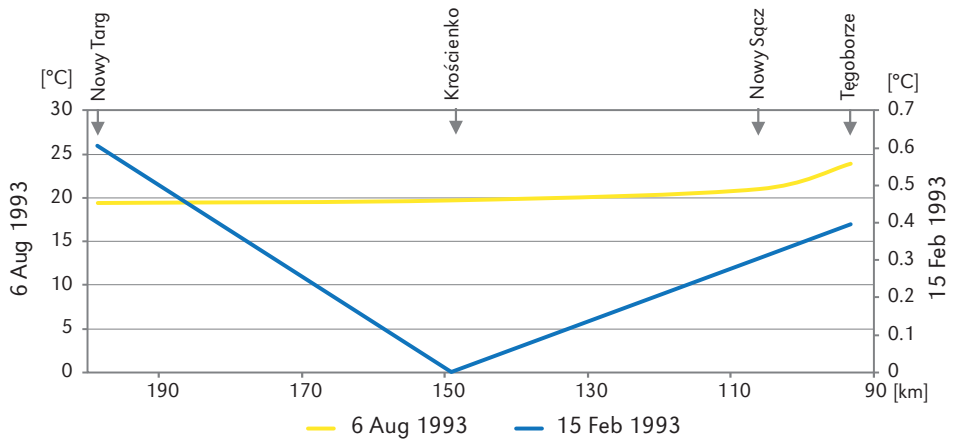

Figure 4. The dynamics of water temperature in the longitudinal profile of the Dunajec River in 1993 (based on the Institute of Meteorology and Water Management data)

perature decreased (from $0.6^{\circ} \mathrm{C}$ to $0.0^{\circ} \mathrm{C}$ ). In the following water-gauging profiles, i.e. at the town of Nowy Sacz $(106 \mathrm{~km})$ and the village of Tęgoborze (the Rożnów Reservoir), a slight increase in temperature was reported, respectively, to $0.3^{\circ} \mathrm{C}$ and $0.4^{\circ} \mathrm{C}$.

A comparison of the Dunajec River thermal conditions from the period just before the construction of the Czorsztyn-Sromowce Wyżne Reservoirs, from the late 1940s to the early 1950s, as presented by Gołek (1961), is not possible without a thorough analysis of climate change. In particular, the dynamics of air temperature would need to be included. Nonetheless, it can be assumed that the general trends in water temperature, in the longitudinal profile of the upper and middle Dunajec River over several years before the establishment of the reservoirs, are similar.
There may be differences in temperature values dependent on air temperature.

\section{The Dunajec River thermals after the construction of the reservoir complex}

The summer measurements were taken on 27 July 2012, under low water conditions of the Dunajec River and its tributaries. At this time, air temperature was in the range of $27.0-28.0^{\circ} \mathrm{C}$. Water temperature in the Dunajec River from Nowy Targ to Harklowa $(187.0 \mathrm{~km})$ increased from $20.7^{\circ} \mathrm{C}$ to $21.4^{\circ} \mathrm{C}$ (Fig. 5). In the Czorsztyn Reservoir backwater $(184 \mathrm{~km})$, air temperature was slightly lower $\left(21.2^{\circ} \mathrm{C}\right)$, while in the reservoir itself the air temperature ranged from $23.3^{\circ} \mathrm{C}$ to $23.5^{\circ} \mathrm{C}$. Slightly higher values were recorded in the

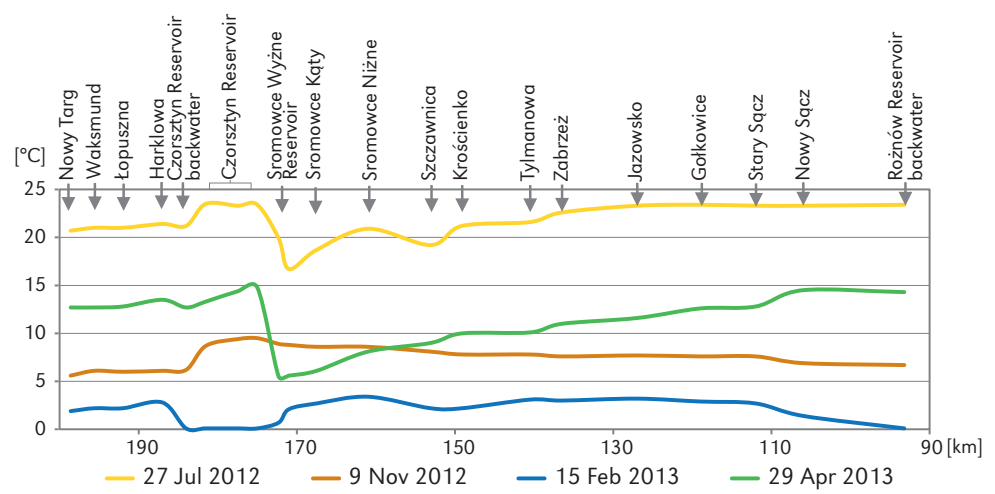

Figure 5. The dynamics of water temperature in the longitudinal profile of the Dunajec River after the construction of the Czorsztyn-Sromowce Wyżne Reservoirs 
upper part of the reservoir due to the faster heating of the water in the shallow layers of the reservoir. On the day the measurements were taken, the water temperature in the surface layer, in the balancing reservoir, was lower by $3.5^{\circ} \mathrm{C}$ from the temperature of the water in the dam part of the main reservoir. Studies by Wiejaczka et al. (2014) showed that the average water temperature in the vertical unit of the Sromowce Wyżne was much lower, compared to the water flowing out from the deeper parts of the Czorsztyn Reservoir. As a result, water flowing from the Sromowce Wyżne Reservoir was cooler than the Dunajec River water flowing into the village of Harklowa's main reservoir (difference of $4.7^{\circ} \mathrm{C}$, Tab. 1). Downstream from the reservoirs, water in the Dunajec River, along the course of the river, was slowly warmed. Then, in Krościenko (about $22 \mathrm{~km}$ from the dam on the Sromowce Wyżne Reservoir), the water reached $21.2^{\circ} \mathrm{C}$ similar to that in the river upstream from the reservoir complex (Fig. 5). The Dunajec River water temperature finally stabilised at Jazowsko (a village $44 \mathrm{~km}$ from the dam of the Sromowce Wyżne Reservoir), reaching $23.3^{\circ} \mathrm{C}$. A similar temperature was recorded to the Rożnów Reservoir backwater.

A different situation took place during the autumn measurements (09 November 2012); under conditions of full cloudiness, air temperature varied from $6.0^{\circ} \mathrm{C}$ to $7.0^{\circ} \mathrm{C}$. Water temperature in the Dunajec River, on the section from Nowy Targ to the Rożnów Reservoir backwater, showed negligible dynamics on that day. Between Nowy Targ and the Czorsztyn Reservoir backwater a slight increase in temperature was recorded, from $5.6^{\circ} \mathrm{C}$ to $6.2^{\circ} \mathrm{C}$ (Fig. 5). In the same backwater, the temperature was $8.7^{\circ} \mathrm{C}$, and in the dam part, it reached $9.5^{\circ} \mathrm{C}$. The surface-layer water temperature in the Sromowce Wyżne Reservoir was lower, only $0.6^{\circ} \mathrm{C}$, from the values recorded in the Czorsztyn Reservoir. The Dunajec River water temperature downstream from the dam, was similar to the value of the balancing reservoir, which means the temperature was $2.7^{\circ} \mathrm{C}$ higher than the temperature of the water flowing into the main reservoir (Tab. 1). Downstream from the dam in Sromowce Wyżne village, the water slightly cooled along the course of the river. In Nowy Sącz and in the Rożnów Reservoir backwater, the temperature stabilised at $6.9-6.7^{\circ} \mathrm{C}$. These values were slightly higher than the Dunajec River water temperature upstream from the Czorsztyn-Sromowce Wyżne Reservoirs $\left(6.1^{\circ} \mathrm{C}\right)$.

The winter-measurements were taken on 15 February 2013, when the air temperature was $0.0-3.0^{\circ} \mathrm{C}$. At this time, the water temperature in the longitudinal profile of the Dunajec River did not show greater variety, and the reservoir influence on the river thermals was not very noticeable. Between the villages of Kowaniec and Harklowa, the Dunajec River water temperature fluctuated between $1.9^{\circ} \mathrm{C}$ and $2.8^{\circ} \mathrm{C}$ (Fig. 5). On the entire Czorsztyn Reservoir, where there was a compact ice cover with a thickness of about $0.4 \mathrm{~m}$, and also in the backwater part, the water

Table 1. The differentiation of inflow and outflow water temperature $\left({ }^{\circ} \mathrm{C}\right)$ from the Czorsztyn and Sromowce Wyżne reservoirs

\begin{tabular}{|l|c|c|c|c|}
\hline \multirow{2}{*}{ Date } & \multicolumn{4}{|c|}{ Temperature $\left({ }^{\circ} \mathrm{C}\right)$} \\
\cline { 2 - 5 } & inflow & $\begin{array}{c}\text { outflow from } \\
\text { Czorsztyn Reservoir }\end{array}$ & $\begin{array}{c}\text { Sutflow from } \\
\text { Sromowce Wyże } \\
\text { Reservoir }\end{array}$ & Dunajec River \\
\hline 4 July 2012 (summer) & 21.3 & 12.7 & 14.6 & 14.4 \\
9 November 2012 (autumn) & 6.1 & 9.5 & 8.7 & 8.8 \\
15 February 2013 (winter) & 2.8 & 2.3 & 2.2 & 2.1 \\
29 April 2013 (spring) & 13.5 & 3.9 & 4.9 & 5.6 \\
\hline
\end{tabular}


temperature was $0.1^{\circ} \mathrm{C}$. In the Sromowce Wyżne Reservoir, an increased water temperature was recorded under ice cover $\left(0.7^{\circ} \mathrm{C}\right)$. The ice cover was present only in the middle of the reservoir. The Dunajec River water temperature downstream from the dam, was significantly higher than that in the balancing reservoir (a difference of $1.4^{\circ} \mathrm{C}$ ) and lower than in the river upstream from the reservoir complex (a difference of $0.7^{\circ} \mathrm{C}$, Tab. 1). Water temperature levelling in relation to the value measured upstream from the reservoir complex was recorded $4 \mathrm{~km}$ downstream from the Sromowce Wyżne Reservoir's dam. Further along the course of the river, over a distance of $7 \mathrm{~km}$, an increase in temperature to $3.4^{\circ} \mathrm{C}$ was recorded. The temperature then decrease to $2.2^{\circ} \mathrm{C}$ at the towns of Szczawnica and Krościenko. In Gołkowice (a village $52 \mathrm{~km}$ below from the Sromowce Wyżne Reservoir dam), the recorded water temperature $\left(2.9^{\circ} \mathrm{C}\right)$ was similar to the water temperature in the Dunajec River, upstream from the reservoir complex $\left(2.8^{\circ} \mathrm{C}\right)$. At the measuring stations, up to Stary Sacz (a town $59 \mathrm{~km}$ below the dam), further warming of the water was recorded. At the town of Nowy Sacz, water temperature decreased to $1.4^{\circ} \mathrm{C}$, due to the inflow of colder waters from the Poprad River $\left(1.7^{\circ} \mathrm{C}\right)$.

In the spring, on 4 April 2013, measurements were carried out when the air temperatures ranged from $23.0^{\circ} \mathrm{C}$ to $24.0^{\circ} \mathrm{C}$. Between the town of Nowy Targ and the village of Harklowa, the water temperature of the Dunajec River was recorded in the range from $12.7^{\circ} \mathrm{C}$ to $13.5^{\circ} \mathrm{C}$ (Fig. 5). In the Czorsztyn Reservoir, the water temperature decreased to $12.7^{\circ} \mathrm{C}$, but increased to $14.8^{\circ} \mathrm{C}$ at the dam. In the Sromowce Wyżne Reservoir, the recorded water surface temperature was lower than in the Czorsztyn Reservoir by $9.3^{\circ} \mathrm{C}$. The Dunajec River water temperature downstream from the balancing reservoir dam was approx. $7.9^{\circ} \mathrm{C}$ lower than upstream from the reservoir complex (Tab. 1). The water temperature in the river approx. $60 \mathrm{~km}$ downstream from the Czorsztyn-Sromowce Reservoirs reached a similar value to the temperature of the Dunajec River water upstream from the reservoirs (Harklowa). At the town of Nowy Sacz, an increase of $1.8^{\circ} \mathrm{C}$ was recorded, in relation to the point located at the town of Stary Sacz. Similarly, as happened during the winter measurements, the aforementioned increase was due to warmer water inflow from the Poprad River $\left(15.5^{\circ} \mathrm{C}\right)$.

The observed changes in water thermals in the longitudinal profile of the Dunajec River middle section, downstream from the Czorsztyn-Sromowce Wyżne Reservoirs, correlate with the changes observed by Cyberska (1972, 1975) downstream from the RożnówCzchów Reservoirs. The author noted that the Rożnów-Czchów Reservoir Complex cools the Dunajec River waters in the spring-summer season and warms them in the autumn and winter. As a result of water contact with the air, the water temperature along the course of the river tends to regain its natural value. The area of the reservoirs' influence on the Dunajec River thermals is, however, observed for most of the year up to the mouth of the Vistula River.

\section{Changes in the annual temperature cycle of the Dunajec River due to the impact of the Czorsztyn-Sromowce Wyżne Complex}

A detailed analysis of the annual cycle of the Dunajec River water temperature was carried out on the basis of the daily values measured in the village of Krościenko in the hydrological years from 1984 to 2007. After the construction of the reservoir complex in 1994-1997, the annual temperature dynamics clearly changed. There were differences within the monthly water-temperature average value, the average maximum, and the average minimum (Fig. 6). Statistical differences between the water temperature values of the Dunajec River at the village of Krościenko for the periods before and after construction of the reservoir complex, are presented in Table 2 and Figure 7. Statistically significant differences 

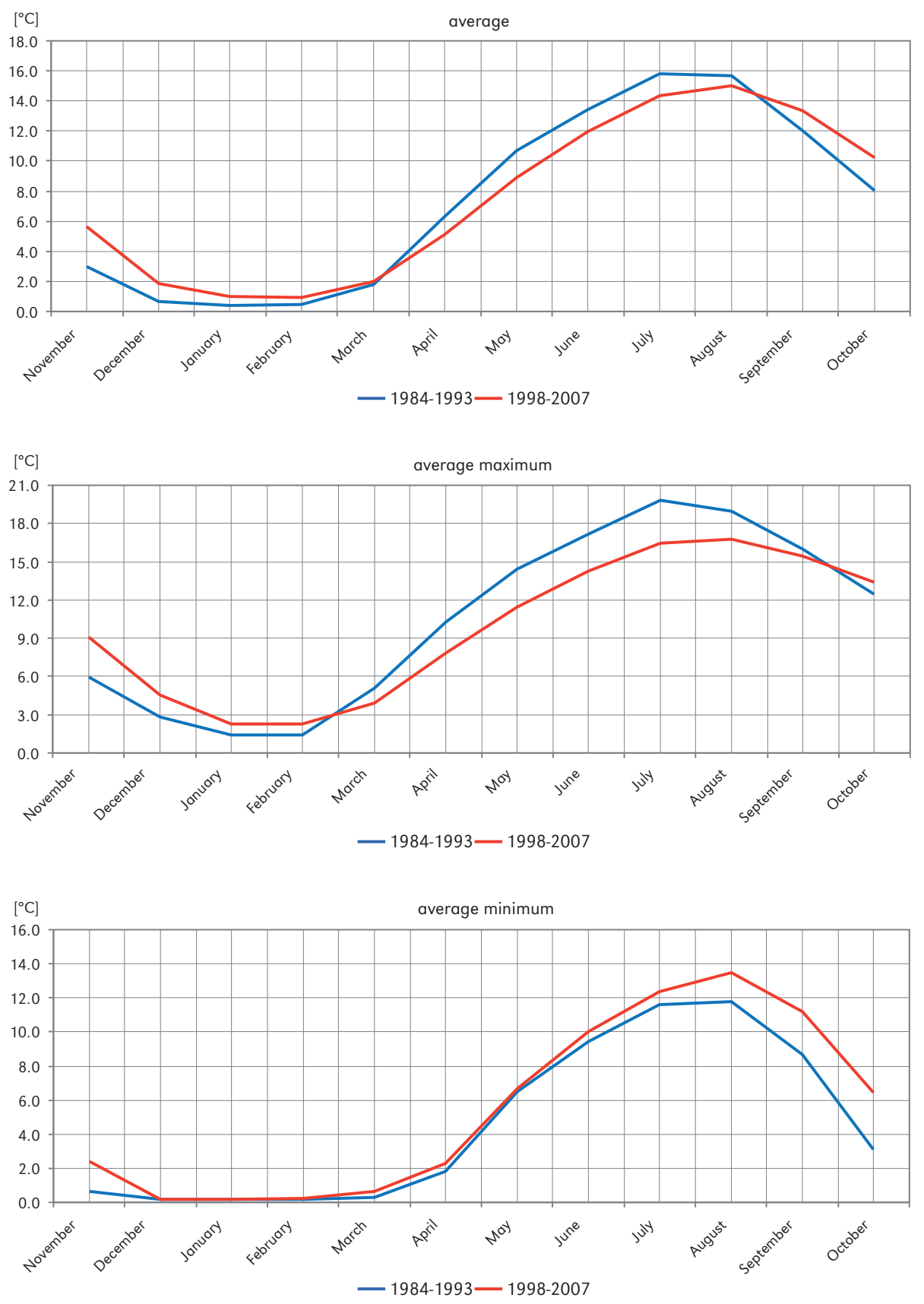

Figure 6. The values of the average, average maximum and average minimum Dunajec River water monthly temperature in Krościenko from 1984 to 2007 (based on the Institute of Meteorology and Water Management data) 
Table 2. Statistical differences of average water temperature values of the Dunajec River in Krościenko between the 1984-1993 (pre-reservoirs) and 1998-2007 (post-reservoirs) periods

\begin{tabular}{|l|l|l|l|l|l|l|l|l|l|l|l|l|}
\hline \multicolumn{10}{|c|}{ Average values } \\
\hline Period & Nov & Dec & Jan & Feb & March & April & May & June & July & Aug & Sep & Oct \\
\hline $1984-1993$ & 3.0 & 0.7 & 0.4 & 0.5 & 1.8 & 6.3 & 10.7 & 13.4 & 15.8 & 15.6 & 12.0 & 8.0 \\
$1998-2007$ & 5.6 & 1.9 & 1.0 & 0.9 & 2.0 & 5.1 & 8.9 & 12.0 & 14.3 & 15.0 & 13.4 & 10.2 \\
\hline \multicolumn{10}{|c|}{ Standard deviation } \\
\hline $1984-1993$ & 1.2 & 0.4 & 0.3 & 0.5 & 1.4 & 1.0 & 1.4 & 1.2 & 1.4 & 1.4 & 0.9 & 0.7 \\
$1998-2007$ & 1.0 & 0.9 & 0.6 & 0.6 & 0.7 & 0.9 & 0.9 & 0.9 & 0.9 & 0.8 & 0.7 & 0.8 \\
\hline \multicolumn{10}{|c|}{ Coefficient of variation (\%) } \\
\hline $1984-1993$ & 39.6 & 61.5 & 80.0 & 103.9 & 75.1 & 15.5 & 12.9 & 9.2 & 8.5 & 8.8 & 7.4 & 9.0 \\
$1998-2007$ & 17.1 & 50.1 & 65.8 & 63.3 & 37.0 & 18.5 & 10.2 & 7.3 & 6.3 & 5.3 & 5.2 & 7.8 \\
\hline
\end{tabular}

were found between the mean month values of the water temperature for the analysed periods $(p<0,05)$, with the exception of March and August $(p=0,31)$.

Prior to the construction of the reservoir complex, the average monthly Dunajec River water temperature ranged annually between $0.4^{\circ} \mathrm{C}$ (January) and $15.8^{\circ} \mathrm{C}$ (July). After the construction of the reservoirs, the average monthly Dunajec River water temperature ranged from $0.9^{\circ} \mathrm{C}$ (February) to $15.0^{\circ} \mathrm{C}$ (August). From April to August, a clear decrease in the average monthly temperatures can be seen. The temperatures ranged from $0.7^{\circ} \mathrm{C}$ (August) to $1.8^{\circ} \mathrm{C}$ (May), but from September to March there was a substantial increase - from $0.2^{\circ} \mathrm{C}$ (March) to $2.6^{\circ} \mathrm{C}$ (November). A levelling off of the average monthly water temperatures took place twice between the periods under consideration in the annual cycle: in March, at a temperature of about $2.5^{\circ} \mathrm{C}$, and in August at about $14.5^{\circ} \mathrm{C}$.

Similar changes can be seen concerning the maximum Dunajec River water temperature. After the construction of the CzorsztynSromowce Wyżne Reservoirs, there were higher maximum monthly temperatures from October to February. The differences ranged from $0.9^{\circ} \mathrm{C}$ (October, January, and February) to $3.2^{\circ} \mathrm{C}$ (November). In the remaining months (March-September), these values were lower than $0.6^{\circ} \mathrm{C}$ (September) to $3.4^{\circ} \mathrm{C}$ (July). In the annual cycle of the monthly average minimum temperature of the Dunajec River water in Krościenko, in the period after the construction of the reservoirs, in all months of the year except for December and January (no change), an increased value is observed. Differences in the course of this temperature ranged between $0.1^{\circ} \mathrm{C}$ (February and May) and $3.4^{\circ} \mathrm{C}$ (October).

The average annual Dunajec River water temperature at Krościenko in the years 1984 -1993 ranged between $6.6^{\circ} \mathrm{C}$ in 1985 and $7.8^{\circ} \mathrm{C}$ in 1990 (Fig. 8). During the establishment of the reservoirs, the average annual temperature decreased to $6.5^{\circ} \mathrm{C}$ in 1996 and $6.6^{\circ} \mathrm{C}$ in 1997. After the construction of the reservoirs, these values increased to between $7.0-8.4^{\circ} \mathrm{C}$, which is slightly higher compared to that observed in the 1984-1993 period. However, the dynamics of these values between successive years is much less than in the previous multi-year period. The average annual temperature for the entire multi-year period, calculated before and after the construction of the reservoirs, is similar; $7.4^{\circ} \mathrm{C}$ and $7.5^{\circ} \mathrm{C}$, respectively.

Slightly larger differences can be seen in the course of the average values of water temperature in the hydrological half-years for the 1984-1993 and 1998-2007 periods (Fig. 8). Before the establishment of the reservoirs, in the winter half-year (November-April), the average water temperature in Krościenko ranged between $1.5^{\circ} \mathrm{C}$ and $2.9^{\circ} \mathrm{C}$. After the construction of the reservoirs, these values 

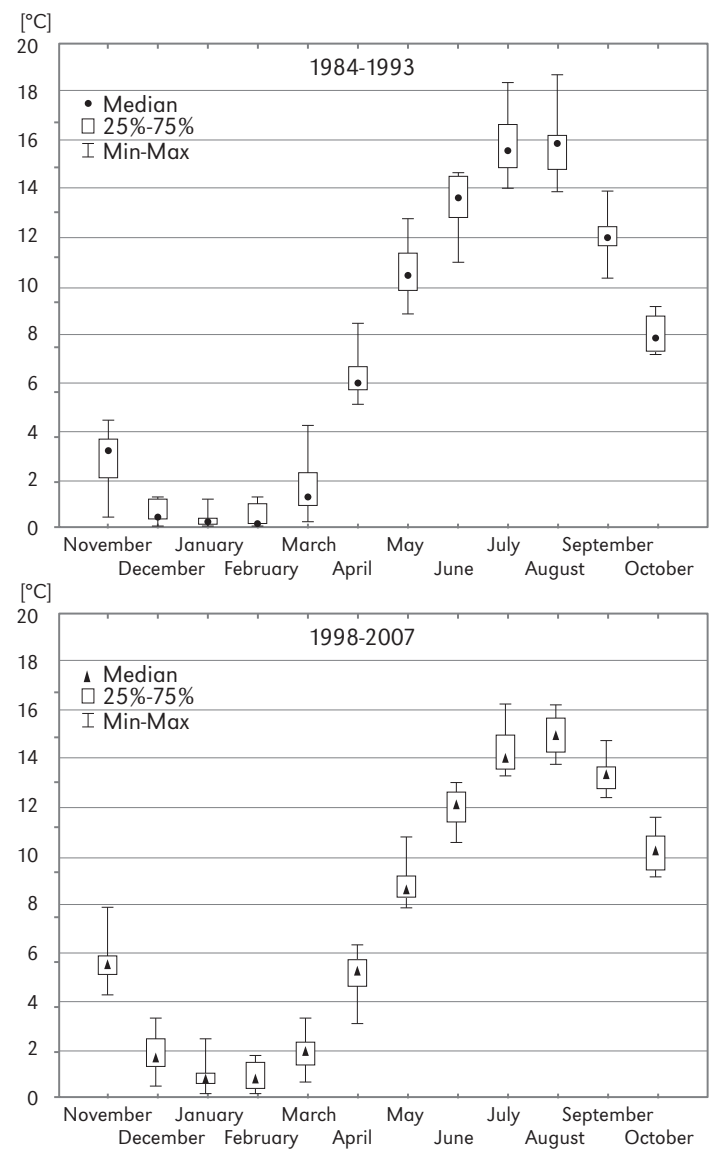

Figure 7. Statistical characteristic of water temperature values of the Dunajec River in Krościenko between the 1984-1993 (pre-reservoirs) and 1998-2007 (post-reservoirs) periods

increased to between $2.1-3.9^{\circ} \mathrm{C}$. The average water temperature of the Dunajec River for the first, winter half-year in the 1998-2007 period was $2.1^{\circ} \mathrm{C}$, and was higher than the average temperature for the period prior to the establishment of the reservoir complex by $0.7^{\circ} \mathrm{C}$. In the case of the summer half-year (May-October) after the construction of the reservoirs, the long-term average water temperature decreased from $12.6^{\circ} \mathrm{C}$ to $12.3^{\circ} \mathrm{C}$. The average water temperature in the summer half of the hydrological years, in individual years of the multi-year period 1998-2007, ranged from $11.6^{\circ} \mathrm{C}$ to $12.9^{\circ} \mathrm{C}$, and were slightly lower compared to the previous 1984 1993 period $\left(11.6-13 \cdot 4^{\circ} \mathrm{C}\right)$.
Change in the thermal regime of the Dunajec River water, as a result of the construction of the Czorsztyn-Sromowce Wyżne Reservoir Complex, can also be seen in the course of the annual water temperature amplitudes of the compared periods (Fig. 9). In the 19841993 period, the amplitudes varied between $18.7^{\circ} \mathrm{C}(1985)$ and $21.9^{\circ} \mathrm{C}(1987)$. In the 1998 2007 period, the values decreased to within the range of $15.7^{\circ} \mathrm{C}(2001)$ to $18.3^{\circ} \mathrm{C}(2007)$.

Similar changes in the annual cycle of the Dunajec River water-temperature downstream from the Rożnów-Czchów Reservoirs were observed by Cyberska (1975). With respect to the water-gauging cross-section at the village of Zgłobice $(23 \mathrm{~km}$ downstream 


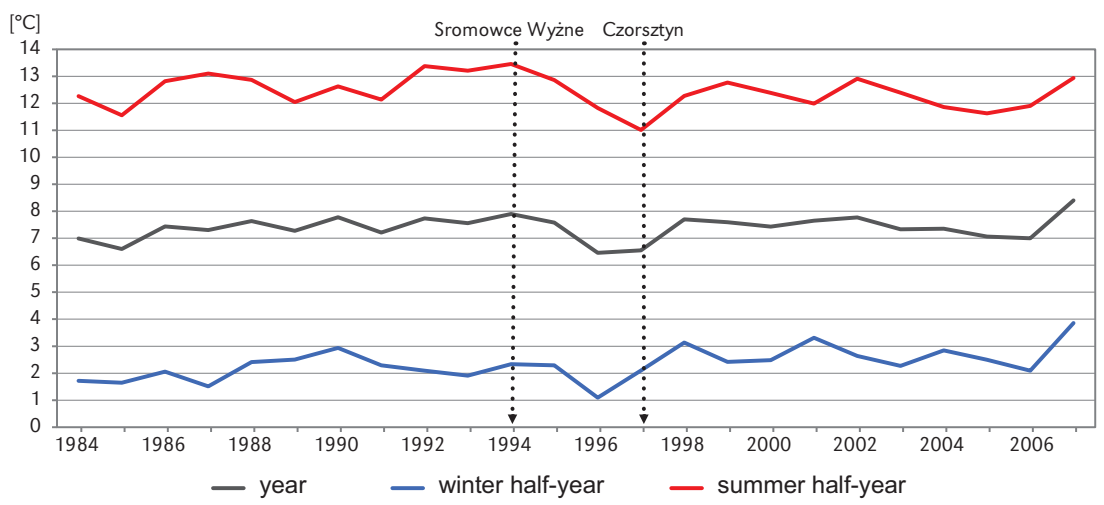

Figure 8. The average Dunajec River water temperature in Krościenko in individual years and half-years of the hydrological multi-year period of 1984-2007 (based on the Institute of Meteorology and Water Management data)

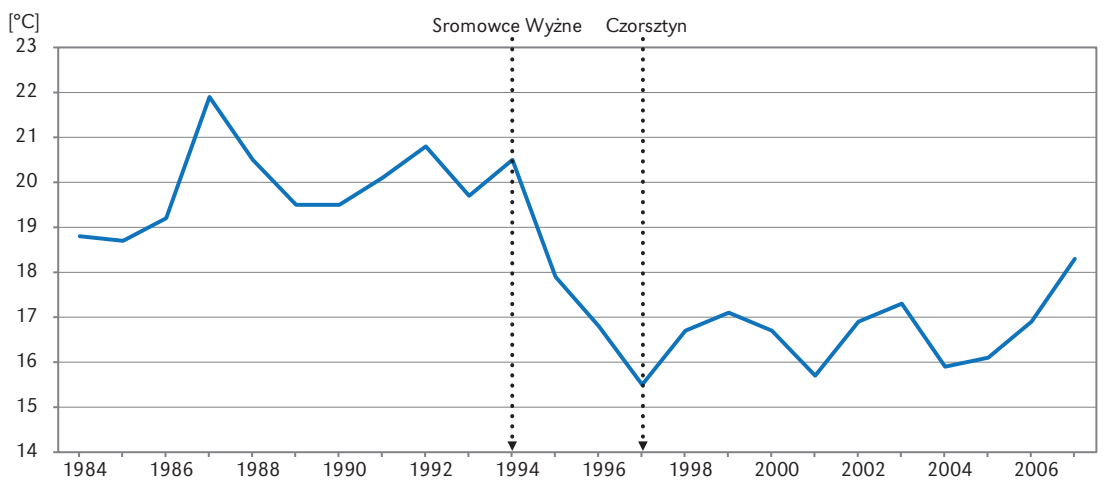

Figure 9. The annual amplitude of water temperature of the Dunajec River in Krościenko in the 19842007 period (based on the Institute of Meteorology and Water Management data)

from the Rożnów-Czchów Reservoirs), after the formation of the reservoirs, the author noted lower average monthly temperature values in the period from March to July and higher monthly temperature values from September to February. Changes in the water temperature of the lower reach of the Dunajec River are due to the operation of the reservoirs. These temperature changes cover entire sections of the river, except in February and August. In February, changes in water temperature were not recorded, and in August these changes reached the $23 \mathrm{rd} \mathrm{km}$. It can be concluded, that the scale of these changes caused by the operation of the RożnówCzchów Reservoir Complex is similar to the scale of the changes at Krościenko down- stream from the Czorsztyn-Sromowce Wyżne Reservoirs.

\section{Summary and conclusion}

The construction of the Czorsztyn-Sromowce Wyżne Reservoirs caused a distinct change in the thermal regime of the middle reach of the Dunajec River. The annual watertemperature cycle has been preserved, but the dynamics of its value has changed. Generally, a warming of the Dunajec River can be seen as a result of the reservoirs' operation in the late autumn, winter, and spring. During the summer and early autumn, though, cooling takes place. The conducted measurements of water temperature in the 
Dunajec River longitudinal profile, show that the scale of change of the water temperature is highest immediately downstream from the dam of the Sromowce Wyżne Reservoir and decreases along the river-course. Water flowing out of the reservoir complex to the river channel when the summer measurements were taken, was $4.7^{\circ} \mathrm{C}$ cooler than the water flowing in. In the winter, the water temperature of the Dunajec River downstream from the reservoirs, was lower by a few tenths of a Celsius degree than upstream from the reservoirs. However, in sub-zero air temperatures, the Czorsztyn-Sromowce Wyżne Reservoir Complex warms the Dunajec River. With total ice cover of the river, water temperature upstream from the reservoirs is close to $0^{\circ} \mathrm{C}$, and the temperature of the water flowing out of the reservoirs is a few Celsius degrees higher.

The determination of the range of impact of the reservoir complex on the Dunajec River water temperature is difficult. Under favorable hydrometeorological conditions, this impact can be felt as far as the Rożnów Reservoir backwater. Not without significance is the water infiltration in the gravel cushioning the bottom of the Dunajec River Channel, and then, the outflow of cooled water, especially noticeable during the summer. The smaller tributaries of the Dunajec River have no significant effect on the water temperature. There was a noticeable impact

\section{References}

Allan J.D., Castillo M.M., 2007. Stream ecology: structure and function of running waters. New York: Springer Science \& Business Media.

CHOMIAK T., 1962. Wpływ zbiornika rożnowskiego na kształtowanie się temperatury wód Dunajca w odpływie ze zbiornika. Gospodarka Wodna, no. 1, pp. 33.

Cyberska B., 1972. Zmiany $w$ temperaturze i zlodzeniu rzek poniżej zbiorników retencyjnych. Gospodarka Wodna, no. 7, pp. 244-250. from the Poprad; the largest tributary of the Dunajec River, during the winter and spring measurements. The influence of the Poprad on shaping the thermals of the Dunajec River, requires further study.

Analysis of archival materials confirmed that the Czorsztyn-Sromowce Wyżne Reservoirs' impact on the thermal regime of the Dunajec River is very visible at the village of Krościenko, which is about $22 \mathrm{~km}$ downstream from the location of the reservoirs. In the period from April to August, a cooling influence of the reservoirs can be noted (an average of $0.7^{\circ} \mathrm{C}$ to $1.8^{\circ} \mathrm{C}$ ), while in the period from September to March - warming takes place (an average of $0.2^{\circ} \mathrm{C}$ to $2.6^{\circ} \mathrm{C}$ ). The average annual Dunajec River temperature amplitude at Krościenko after the construction of the reservoirs, decreased by $3.1^{\circ} \mathrm{C}$.

Given that the main factor influencing water temperature is the air temperature, an interesting study would be to analyse the role of air temperature dynamics in shaping the water temperature of the Dunajec River in the period before and after the construction of the Czorsztyn-Sromowce Wyżne Reservoir Complex.

\section{Editors' note:}

Unless otherwise stated, the sources of tables and figures are the authors', on the basis of their own research.

Cyberska B., 1975. Wpływ zbiornika retencyjnego na transformację naturalnego reżimu termicznego rzeki. Prace IMGW, no. 4, pp. 45-108.

DYNOWSKA I., 1971. Typy reżimów rzecznych w Polsce. Zeszyty Naukowe Uniwersytetu Jagiellońskiego, vol. 268, Prace Instytutu Geograficznego Uniwersytetu Jagiellońskiego, vol. 50, Kraków: Uniwersytet Jagielloński.

Frutiger A., 2004. Ecological impacts of hydroelectric power production on the River Ticino. Part 2: Effects on the larval development of the dominant benthic macroinvertebrate (Alloga- 
mus auricollis, Trichoptera). Archiv für Hydrobiologie, vol. 159, no. 1, pp. 57-75.

Gotek J., 1961. Termika rzek polskich. Prace PIHM, no. 62 , pp. 1-79.

Kıoss A. (ed.), 2003. Zespół Zbiorników Wodnych Czorsztyn-Niedzica i Sromowce Wyżne im. Gabriela Narutowicza. Monografia. Warszawa: RZGW w Krakowie, Hydroprojekt Warszawa, IMGW.

Lessard J.L., Hayes D.B., 2003. Effects of elevated water temperature on fish and macroinvertebrate communities below small dams. River Research and Applications, vol. 19, no. 7, pp. 721-732.

Punzet J., 1991. Wpływ zespołu zbiorników Rożnów-Czchów na reżim wodny Dunajca. Gospodarka Wodna, no. 6, pp. 122-126.

SmoŁkowicz W., Wiejaczka Ł., Soja R., 2014. Ocena zasięgu oddziaływania zbiornika Klimkówka na termikę rzeki Ropy. Monitoring Środowiska Przyrodniczego, no. 16, pp. 59-64.

Soja R., WiEjACZKA Ł., 2014. The impact of a reservoir on the physicochemical properties of water in a mountain river. Water and Environment Journal, vol. 28, no. 4, pp. 473-482.

Tомік T., 1969. Próba charakterystyki termicznej zbiornika rożnowskiego. Prace PIHM, no. 96, pp. 43-55.
WebB B.W., Walling D.E., 1993. Temporal variability in the impact of river regulation on thermal regime and some biological implications. Freshwater Biology, vol. 29, no. 1, pp. 167-182.

WIEJACZKa Ł., 2007a. Dobowy cykl temperatury wody w rzece Ropie poniżej zbiornika retencyjnego w Klimkówce. Monitoring Środowiska Przyrodniczego, no. 8, pp. 91-98.

WIEJACZKA Ł., 2007b. Wpływ zbiornika wodnego „Klimkówka” na reżim termiczny rzeki Ropy [in:] A. Kostrzewski, A. Andrzejewska (eds.), Program Zintegrowanego Monitoringu Środowiska Przyrodniczego a zadania ochrony obszarów Natura 2000, Biblioteka Monitoringu Środowiska, Izabelin, pp. 367-378.

WIEJACZKA Ł., 2011. Wpływ zbiornika wodnego "Klimkówka" na abiotyczne elementy środowiska przyrodniczego w dolinie rzeki Ropy. Prace Geograficzne, 219, Warszawa: Instytut Geografii i Przestrzennego Zagospodarowania PAN.

Wiejaczka Ł., Kijowska-StrugaŁa M., PierwoŁA P., NowaK M., 2014. Termiczna charakterystyka zespołu zbiorników Czorsztyn-Sromowce Wyżne. Gospodarka Wodna, no. 1, pp. 28-36.
(C) Łukasz Wiejaczka et al.

(C) Geographia Polonica

(C) Institute of Geography and Spatial Organization

Polish Academy of Sciences - Warsaw • 2015
Article first received • May 2014

Article accepted • June 2015 
http://rcin.org.pl 